\title{
OPTIMALISASI LIMBAH AIR CUCIAN BERAS SEBAGAI PUPUK ORGANIK CAIR DALAM MENDUKUNG KETAHANAN PANGAN KELUARGA DI DESA TEGALAN KABUPATEN KEDIRI
}

\author{
Nugraheni Hadiyanti ${ }^{1}$ Bambang Dwi Moeljanto ${ }^{2}$, Nu Khabibi ${ }^{3}$ \\ ${ }^{123}$ Fakultas Pertanian Universitas Kadiri Kediri Jawa Timur \\ E-mail: nugraheni@unik-kediri.ac.id
}

Article History:

Received: 20-02-2021

Revised: 01-03-2021

Accepted: 14-04-2021

Keywords: Air cucian beras, Ketahanan pangan, Pupuk organik cair

\begin{abstract}
Pengelolaan limbah rumah tangga terus digalakkan untuk memberikan nilai tambah terhadap barang-barang yang tidak berguna dan mengatasi masalah lingkungan. Tujuan dari kegiatan ini adalah usaha memberdayakan masyarakat dalam mengolah limbah air cucian beras menjadi pupuk organik cair dalam mendukung ketahanan pangan rumah tangga. Air cucian beras mempunyai kandungan yang bermanfaat bagi pertumbuhan dan perkembangan tanaman, mudah diperoleh, harga terjangkau dan ramah lingkungan. Kegiatan pengabdian masyarakat dilaksanakan di Desa Tegalan, Kecamatan Kandat, Kabupaten Kediri, meliputi presentasi, pelatihan dan pendampingan dalam pengolahan limbah air cucian beras maupun saat aplikasi ke tanaman. Masyarakat menyambut baik dan antusias dalam mengolah limbah air cucian beras karena bahan tersedia di rumah tangga setiap hari. Pupuk organik cair dari limbah air cucian beras sebagai pengganti pupuk kimia meningkatkan produktivitas tanaman dan mengurangi biaya dalam pengelolaan pekarangan maupun usaha pertanian di lahan. Pembuatan pupuk organik dari limbah air cucian beras salah satu upaya mewujudkan pertanian organik di Indonesia.
\end{abstract}

\section{Pendahuluan}

Usaha pertanian baik di lahan pekarangan maupun lahan sawah masih menjadi andalan program Pemerintah dalam upaya mengoptimalkan potensi setiap daerah, tidak terkecuali di Desa Tegalan Kecamatan Kandat Kabupaten Kediri. Desa Tegalan Kecamatan Kandat merupakan salah satu Desa di Kabupaten Kediri yang letaknya $10 \mathrm{~km}$ dari pusat pemerintahan kotamadya.Batas wilayah Desa Tegalan adalah: sebelah utara Desa Pule, selatan Desa Kandat, timur Desa Ngletih dan barat Desa Ringinsari. Lahan di Desa Tegalan digunakan untuk tanah sawah, tanah kering, tanah perkebunan dan fasilitas umum.Mata pencaharian masyarakat Desa Tegalan sebagian besar sebagai peternak maupun petani. 
Kegiatan pengabdian masyarakat tentang pengoptimalan air cucian beras sebagai pupuk organik cair merupakan bentuk pemberdayaan masyarakat Desa Tegalan Kecamatan Kandat dalam mengelola limbah rumah tangga. Selain untuk meningkatkan ketrampilan juga mengembangkan ekonomi kreatif masyarakat sekitar. Pengelolaan limbah rumah tangga menjadi pupuk organik sudah banyak diteliti dan sebagian sudah diterapkan di masyarakat. Penggunaan pupuk organik semakin digalakkan mengingat semakin banyak lahan pertanian rusak akibat pemakaian pupuk kimia yang berlebihan. Pupuk organik berperngaruh baik apabila digunakan dalam jangka panjang karena sifatnya menggemburkan tanah dan meningkatkan kemampuan tanah menyimpan air, sehingga kesuburan tanah tetap terjaga. Sementara itu pupuk kimia sintetis walaupun efek reaksinya cepat, secara jangka panjang akan mengeraskan tanah dan mengurangi kesuburannya (Susetya, 2012).

Salah satu limbah rumah tangga yang belum banyak dimanfaatkan padahal potensial dikembangkan sebagai pupuk organik cair adalah air cucian beras. Potensi air cucian beras sebagai pupuk organik cair sangat membantu masyarakat dalam mengembangkan usaha pertanian baik di pekarangan maupun di lahan pertanian. Hal ini juga sebagai usaha pengoptimalan pemanfaatan pekarangan dalam mendukung ketahanan pangan keluarga. Menurut Ariyanti et al. (2018), air cucian beras merupakan salah satu pupuk limbah yang kurang dimanfaatkan oleh manusia, padahal limbah tersebut telah terbukti dapat membantu menyuburkan tanaman. Air cucian beras merupakan limbah yang berasal dari proses pembersihan beras yang akan dimasak. Konsumsi beras yang tinggi menyebabkan banyaknya air cucian beras yang terbuang dan jarang untuk dimanfaatkan. Survei Sosial Ekonomi Nasional yang dilakukan oleh Badan Pusat Statistik (BPS) pada tahun 2015 menjelaskan bahwa konsumsi beras di Indonesia per kapita yaitu sebesar $98 \mathrm{~kg} / \mathrm{tahun}$. Jumlah tersebut meningkat dibandingkan tahun 2014 yaitu sebesar $97.2 \mathrm{~kg} / \mathrm{tahun}$.

Limbah cucian air beras merupakan hasil buangan yang berasal dari suatu proses produksi baik industri maupun domestik (rumah tangga) yang mengandung senyawa organik dan mineral. Kandungannya antara lain karbohidrat, nitrogen, fosfor, kalium, magnesium, sulfur, besi, Vitamin B1 (Wulandari, 2013). Cara pengolahan pupuk organik cair dari limbah air cucian beras mudah dan bisa dilakukan sendiri oleh masyarakat serta biaya yang terjangkau. Air cucian beras mempunyai banyak manfaat untuk tanaman, mudah diperoleh petani dan ramah lingkungan memiliki harga yang murah sehingga dapat terjangkau oleh petani (Kalsum et al., 2011). 
Beberapa hasil penelitian menunjukkan bahwa pupuk organik cucian beras dapat meningkatkan pertumbuhan dan perkembangan tanaman. Pupuk organik cucian beras efektif dalam meningkatkan pertumbuhan tanaman sawi hijau terlihat pada tinggi tanaman dan jumlah daun (Hairuddin, 2015). Pengaruh pemberian air cucian beras merah memberikan pengaruh nyata $(\mathrm{P}>0,05)$ terhadap pertumbuhan vegetatif tanaman lada yang meliputi jumlah daun, berat basah dan berat kering (Baning et al., 2016). Limbah air cucian beras berpotensi pengganti pupuk kimia dan mampu meningkatkan pertumbuhan tanaman pakcoy karena mengandung senyawa organik yang dapat dimanfaatkan sebagai sumber hara (Ilhamdi et al., 2019).

\section{Metode}

Kegiatan dalam pengabdian masyarakat dimulakan dengan persiapan sebelum terjun ke masyarakat. Pada tahap persiapan meliputi koordinasi dan sosialisasi baik kepada pemuka maupun masyarakat setempat. Sasaran dalam kegiatan pengabdian masyarakat ini adalah warga sekitar di Desa Tegalan, utamanya yang bekerja sebagai petani. Pemilihan sasaran inti sebanyak kurang lebih 20 peserta berdasarkan hasil sosialisasi terhadap masyarakat yang menunjukkan keinginan dan antusias untuk mengikuti kegiatan ini. Pada tahap persiapan juga dilakukan observasi terkait permasalahan yang sedang dihadapi petani khususnya dan masyarakat pada umumnya dalam usaha pemanfaatan pekarangan maupun budidaya pertanian di lahan.

Koordinasi dan sosialisasi dengan pemuka maupun masyarakat setempat. Sasaran dalam kegiatan pengabdian masyarakat ini adalah warga sekitar di Desa Tegalan, utamanya yang bekerja sebagai petani. Pemilihan sasaran inti sebanyak kurang lebih 20 peserta berdasarkan hasil sosialisasi terhadap masyarakat yang menunjukkan keinginan dan antusias untuk mengikuti kegiatan ini. Pada tahap persiapan juga dilakukan observasi terkait permasalahan yang sedang dihadapi petani khususnya dan masyarakat pada umumnya dalam usaha pemanfaatan pekarangan maupun budidaya pertanian di lahan.

Pemberian materi dan pengarahan kepada masyarakat/sasaran tentang pupuk organik. Tujuan dari pendidikan kepada masyarakat adalah untuk menyampaikan manfaat pupuk organik dalam budidaya tanaman, pengolahan limbah air cucian beras menjadi pupuk organik cair dan pemanfaatan lahan pekarangan agar berhasil guna dan berdaya guna. Kebanyakan lahan pekarangan yang belum dimanfaatkan secara maksimal oleh masyarakat. Pengelolaan 
lahan pekarangan bermanfaat sebagai penambah keindahan rumah sehingga lebih asri, mencukupi kebutuhan sayuran dan buah-buahan secara mandiri, persediaan tanaman obat keluarga dengan biaya relatif murah dan perawatan yang mudah.

Tahap demonstrasi adalah praktek langsung dalam pembuatan pupuk organik cair dari limbah air cucian beras. Sebelum proses pembuatan, terlebih dahulu dipersiapkan bahan dan alat yang diperlukan. Bahan yang digunakan adalah air cucian beras, EM4 dan molase, sedangkan alatnya adalah ember atau jerigen yang ada tutupnya. Tahapan pembuatan pupuk organik cair dari limbah air cucian beras adalah menyiapkan 1 lt air cucian beras, $10 \mathrm{ml}$ EM4, $10 \mathrm{ml}$ molase. Kemudian semua bahan tersebut dicampur menjadi satu. Setelah itu menyiapkan jerigen yang tutupnya sudah dilubangi dan dikasih selang untuk lubang udara agar tidak meledak. Bahan yang sudah dicampur dimasukkan ke dalam jerigen dan difermentasikan kurang lebih dua minggu.

Pendampingan dilakukan baik pada saat pembuatan pupuk organik cair maupun aplikasi ke tanaman. Pendampingan bertujuan agar tata cara pembuatan pupuk organik cair dan aplikasi ke tanaman sesuai aturan/prosedur sehingga memberikan hasil yang baik. Kegiatan pengabdian masyarakat dievaluasi berdasarkan: pemahaman sasaran terhadap materi yang diberikan, ketrampilan sasaran dalam pembuatan pupuk organik cair dari limbah air cucian beras dan kualitas tanaman dilihat dari pertumbuhannya setelah aplikasi pupuk organik cair.

\section{Hasil dan Pembahasan}

Kegiatan pengabdian masyarakat dilaksanakan di Desa Tegalan Kecamatan Kandat Kabupaten Kediri merupakan bentuk pemberdayaan masyarakat dalam memanfaatkan limbah rumah tangga. Salah satu limbah rumah tangga yaitu air cucian beras bisa diolah menjadi POC yang mempunyai nilai tambah dan mengembangkan ekonomi kreatif masyarakat. Secara umum kegiatan pengabdian masyarakat ini berjalan dengan baik, lancar dan mendapat sambutan positif dari masyarakat setempat. Kegiatan ini bertujuan memberikan wawasan dan keilmuan kepada masyarakat luas tentang pemanfaatan limbah rumah tangga khususnya air cucian beras sebagai pupuk organik cair.

Penggunaan pupuk organik baik bentuk padat maupun cair terus digalakkan dalam usaha pertanian untuk mewujudkan pertanian berkelanjutan. Bahan-bahan organik untuk pembuatan pupuk organik bisa menggunakan berbagai limbah rumah tangga yang ada 
disekeliling kita. Air cucian beras merupakan salah satu limbah rumah tangga yang potensial untuk pupuk organik cair (POC). POC dari limbah air cucian beras selain murah bahan-

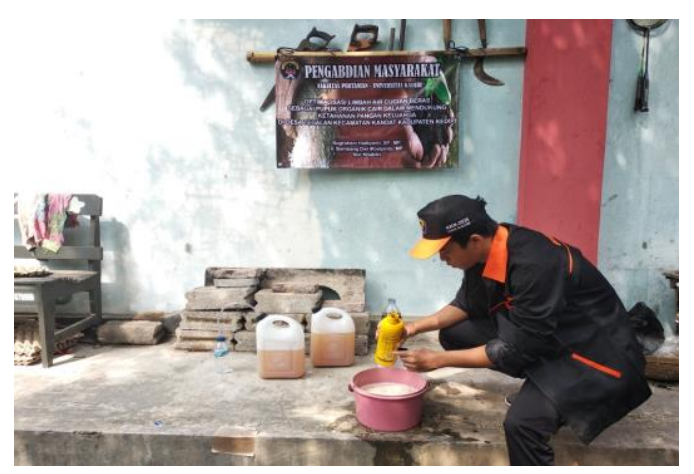
bahannya, pembuatannya mudah, dan berkhasiat dalam meningkatkan hasil dalam usaha pertanian.

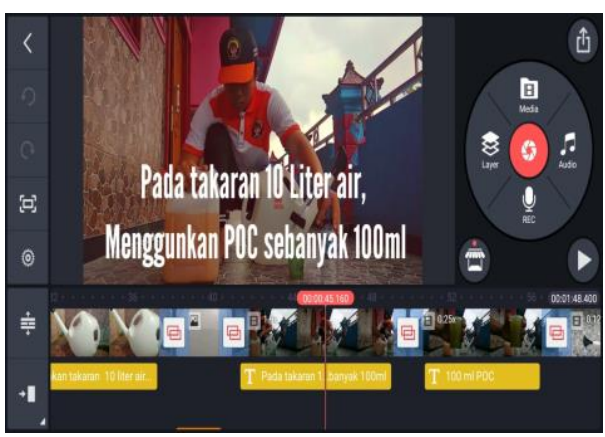

Gambar 1. Proses pembuatan POC dari limbah air cucian beras

Kegiatan penyuluhan dalam rangka pemberian materi dan pengarahan kepada masyarakat tentang pupuk organik dilakukan presentasi secara online mengingat dalam kondisi pandemi Covid-19 menggunakan google meet maupun wa. Dengan segala keterbatasan secara online akan tetapi antusias masyarakat cukup bagus. Respon masyarakat cukup baik dengan memberikan tanggapan terkait materi yang disampaikan. Ada beberapa tanggapan maupun pertanyaan yang disampaikan oleh beberapa peserta prsentasi.

Tanggapan dari salah satu warga yaitu Ibu Lilik Fatmawati adalah sosialisasi manfaat dan cara pengolahan air limbah cucian beras menjadi POC ini sangat membantu dan menarik, karena menyajikan ilmu serta wawasan baru dan cara penyampaian materi yang mudah dipahami masyarakat, serta pembuatan POC dari air cucian beras ini dinilai mudah karena bahan dan alatnya yang mudah diakses. Ibu Dwi Susanti juga mengatakan bahwa cara mengaplikasikan POC dari air cucian beras ini dinilai mudah, dikarenakan tidak berbahaya dan aman penggunaannya serta materi yang disajikan oleh pemateri tergolong mudah dipahami. Menurut Ibu Triani, sosialisasi dan pengarahan tersebut juga membuka pikiran anak-anak muda Desa Tegalan untuk mengembangkan ide - ide kreatif dalam menunjang perekonomian masyarakat. Pembuatan POC dari air beras ini sangat mudah dipraktekkan, terjangkau harganya dan tidak memakan waktu lama dalam membuatnya. Disamping itu POC dari air beras ini dapat meringankan pengeluaran pupuk.

Beberapa kegiatan pengabdian masyarakat ini juga dilakukan secara langsung dengan terjun ke kelompok-kelompok kecil masyarakat. Kegiatan demonstrasi atau pelatihan pembuatan pupuk organik cair dari air limbah cucian beras, pembagian pupuk organik cair 
(POC) dari limbah cucian beras, pembagian tanaman organik dan pengecekan/pengontrolan tanaman setelah aplikasi POC dari limbah cucian beras. Pelatihan pembuatan POC dari limbah air cucian beras dilakukan pada beberapa titik kelompok sehingga warga dapat melihat langsung proses pembuatannya.
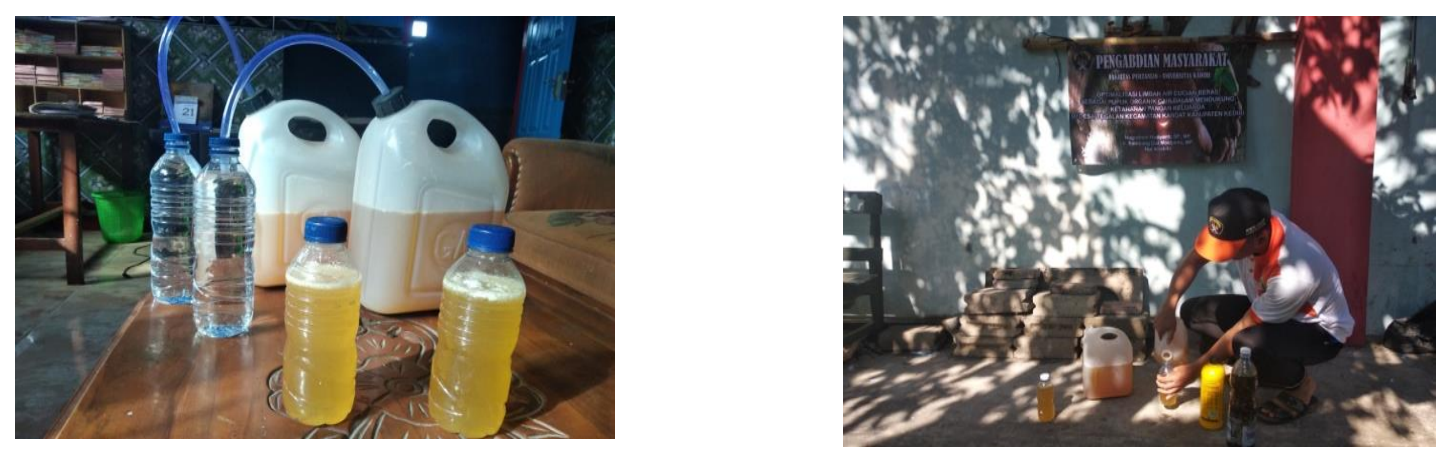

Gambar 2. Packaging POC agar siap pakai

Berdasarkan pengamatan di lapangan, masyarakat Desa Tegalan Kecamatan Kandat termasuk masyarakat yang terbuka, artinya mudah menerima hal-hal dan wawasan baru apalagi yang bermanfaat bagi kehidupan mereka sehari-hari. Adanya sosialisasi ini juga mendorong dan memotivasi masyarakat agar terpacu dalam memunculkan ide-ide yang ditujukan untuk memenuhi ketahanan pangan keluarga dan melakukan kegiatan yang produktif serta kreatif. POC dari limbah organk selain menggantikan pupuk kimia yang selama ini banyak digunakan juga untuk memperbaiki struktur tanah. Selain itu dengan penggunaan POC diharapkan mengurangi biaya produksi dalam usaha pertanian.
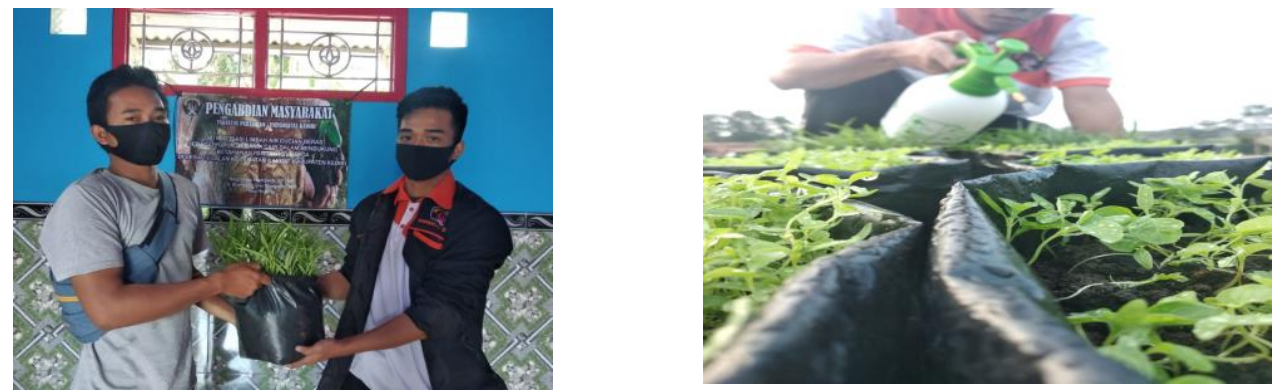

Gambar 3. Perawatan dan pembagian tanaman ke masyarakat

Berdasarkan pengamatan di lapangan, masyarakat Desa Tegalan Kecamatan Kandat termasuk masyarakat yang terbuka, artinya mudah menerima hal-hal dan wawasan baru apalagi yang bermanfaat bagi kehidupan mereka sehari-hari. Adanya sosialisasi ini juga mendorong dan memotivasi masyarakat agar terpacu dalam memunculkan ide-ide yang ditujukan untuk memenuhi ketahanan pangan keluarga dan melakukan kegiatan yang 
produktif serta kreatif. POC dari limbah organk selain menggantikan pupuk kimia yang selama ini banyak digunakan juga untuk memperbaiki struktur tanah. Selain itu dengan penggunaan POC diharapkan mengurangi biaya produksi dalam usaha pertanian.

Pembuatan POC dari limbah air cucian beras yang relatif mudah, cepat dan biaya yang murah memberikan keuntungan dan nilai tambah bagi barang-barang yang selama ini dianggap tidak berguna. Peran serta semua pihak sangat dibutuhkan dalam usaha pengelolaan limbah rumah tangga tidak terkecuali pemerintah desa setempat sebagai pengatur dan pengambil kebijakan di tingkat bawah. Kesadaran masyarakat akan tumbuh dengan sendirinya manakala ada dorongan dan pengarahan secara terus menerus dan berkesinambungan.

Pendampingan baik dalam pembuatan POC dari limbah air cucian beras maupun perawatan tanaman berjalan dengan baik artinya masyarakat bisa mengikuti arahan dengan baik dan antusias. Pendampingan dilakukan secara door to door dengan mengambil beberapa peserta saja. Dari peserta yang mendapat pendampingan langsung kemudian diminta membagikan keilmuan dan pengalaman terkait POC dair limbah air cucian beras kepada tetangga-tetangga terdekat. Hal ini cukup efektif dan efisien dalam kegiatan ini karena masyarakat bias mendapat informasi langsung dari orang yang relatif sudah saling mengenal dan tidak membahayakan karena masih masa pandemi covid-19. Kegiatan pembagian tanaman yang sudah menggunakan apilkasi POC air cucian beras sebagai bentuk sosialisasi budidaya tanaman dengan pupuk organik yang mudah dan murah.

\section{Kesimpulan}

Pemanfaatkan limbah air cucian beras menjadi pupuk organik cair merupakan usaha pemberdayaan masyarakat dalam mengelola potensi yang ada di lingkungan setempat khususnya di Desa Tegalan kabupaten Kediri. Kegiatan penyuluhan sekaligus pelatihan pembuatan pupuk organik cair sangat bermanfaat untuk mendukung ketahanan pangan keluarga sehingga berdaya guna secara ekonomi dan teknis.

\section{Ucapan Terima kasih}

Terima kasih kami sampaikan kepada Lembaga Pengembangan, Penelitian dan Pengabdian Masyarakat (LP3M) Universitas Kadiri atas bantuan dana dalam pelaksanaan pengabdian masyarakat tahun 2020 . 


\section{Daftar Referensi}

Ariyanti, M., Suherman, C., Rosniawaty, S., \& Franscyscus, A. (2018). Pengaruh Volume dan Frekuensi Pemberian Air Cucian Beras Terhadap Pertumbuhan Bibit Tanaman Karet (Hevea brasiliensis Muell.) Klon GT 1. Paspalum: Jurnal Ilmiah Pertanian. https://doi.org/10.35138/paspalum.v6i2.94

Baning, C., Rahmata, H., \& Supriatno. (2016). Pengaruh pemberian air cucian beras merah terhadap pertumbuhan vegetatif tanaman lada (Piper nigrum L.). Ilmiah Mahasiswa Pendidikan Biologi.

Hairuddin, R. (2015). EFEKTIFITAS PUPUK ORGANIK AIR CUCIAN BERAS TERHADAP PERTUMBUHAN TANAMAN SAWI HIJAU (Brassica juncea L). EFEKTIFITAS PUPUK ORGANIK AIR CUCIAN BERAS TERHADAP PERTUMBUHAN TANAMAN SAWI HIJAU (Brassica Juncea L) Rahman.

Ilhamdi, M. L., Handayani, Y., Saputri, A., Anjani, M., Najjah, S. S., Yulianingsih, E., Rahmatullah, T. M., Marzia, E., Yogasworo, A., Mustakim, M., \& Wira P., I. D. G. (2019). Penyuluhan, Pelatihan dan Pendampingan Pengelolaan Limbah Rumah Tangga Menjadi Pupuk Organik di Desa Kerumut Kecamatan Pringgabaya. Jurnal Pengabdian Magister Pendidikan IPA. https://doi.org/10.29303/jpmpi.v1i2.300

Kalsum, U., Fatimah, S., \& Catur, W. (2011). Efektivitas Pemberian Air Leri Terhadap Pertumbuhan dan Hasil Jamur Tiram Putih (Pleurotus ostreatus). Jurnal Agrovigor.

Susetya, D. (2012). Panduan Lengkap Membuat Pupuk Organik (Untuk Tanaman Pertanian dan Perkebunan) (Pustaka Baru Press (ed.)).

Wulandari, C. M. dan T. (2013). Pengaruh Air Cucian Beras Merah dan Beras Putih Terhadap Pertumbuhan dan Hasil Selada (Lactuca sativa L.). https://doi.org/10.22146/veg.1516 